\title{
EXPERIÊNCIA VIVENCIADA DURANTE A MOBFOG COM ALUNOS DO ENSINO MÉDIO DO SERTÃO CENTRAL PERNAMBUCANO
}

\author{
Apresentação: Relato de Experiência \\ Francisca Rejane Barros Freire ${ }^{1}$;Emanoel Silva Carvalho ${ }^{2}$;Maria Leonete da Silva ${ }^{3}$;Eriverton da \\ Silva Rodrigues ${ }^{4}$.
}

\section{Introdução}

A Mostra Brasileira de Foguetes (MOBFOG) é organizada anualmente pela Sociedade Astronômica Brasileira (SAB) em parceria com a Agência Espacial Brasileira (AEB). As equipes têm o objetivo de lançar um foguete feito de garrafa PET e obter o maior alcance possível. A única limitação é o ar que deve ser bombeado dentro da garrafa até atingir a sua pressão adequada e as equipes tem direito a dois lançamentos, sendo classificados de acordo com o melhor alcance atingido. Este projeto partiu do pressuposto que o público interessado possa compreender o significado do estudo da Astronomia. (SAMPAIO e RODRIGUES, 2015)

\section{Relato de Experiência}

Através do Programa Institucional de Bolsas de Iniciação à Docência (PIBID) em parceria com o Programa Despertando Vocações para as Licenciaturas (PDVL) no Instituto Federal de Educação, Ciência e Tecnologia do Sertão Pernambucano (IF Sertão-PE campus Salgueiro), onde participou-se da capacitação de construção de foguetes que foi realizada no dia 29 de abril de 2016 para posteriormente auxiliar os estudantes do Ensino Médio durante a MOBFOG. Foi feito a divulgações através de cartazes na instituição e oralmente nas salas de aula, contribuindo para o interesse e curiosidade dos alunos, motivando-os a participar o que os deixou bastantes ansiosos pelo acontecimento do evento. As equipes trouxeram os materiais necessários para a construção dos

\footnotetext{
${ }^{1}$ Licenciatura em Física, Instituto Federal do Sertão Pernambucano Campus Salgueiro, rejanebarros2014@hotmail.com 2 Licenciatura em Física, Instituto Federal do Sertão Pernambucano Campus Salgueiro, emanoelcarvalho911@hotmail.com

3 Licenciatura em Física, Instituto Federal do Sertão Pernambucano Campus Salgueiro, mariaLeonetefisica@hotmail.com

${ }^{4}$ Mestre em Física, Instituto Federal do Sertão Pernambucano Campus Salgueiro, erivertonr@hotmail.com
} 
foguetes, no dia da oficina que foi ministrada para esse fim, a mesma realizada em 11 de maio de 2016. Durante a oficina mostrou-se o passo a passo da construção do foguete e buscou-se incentivar os alunos através de um vídeo sobre a viagem do astronauta Marcos Pontes e sua missão na estação espacial internacional, nesse momento percebeu-se o quanto os discentes ficaram entusiasmados com a atividade. Após estas etapas, os foguetes foram construídos pelos alunos (Imagem1) sob a orientação do grupo o qual dividiu os mesmos em quatro equipes. No dia 19 de maio de 2016 houve o lançamento às 16:00 h com muita animação (Imagem 1), o prazer em participar deste momento e o contato direto com os alunos foi enriquecedor para a formação docente da equipe organizadora .

Imagem 1: Construção e lançamento de foguetes de garrafa PET com os alunos do $1^{\circ}$ ano.Fonte: Próprio autor.
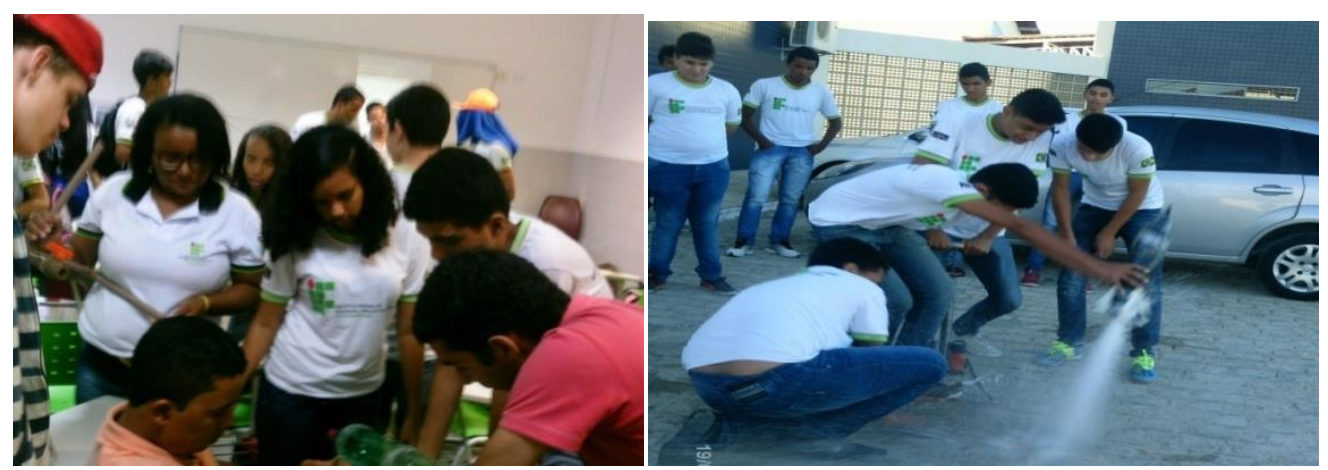

Além disso, os autores do trabalho desenvolvem um projeto de extensão voltado à divulgação e popularização da Astronomia no IF Sertão-PE campus Salgueiro o qual posteriormente será implantado nas escolas da região. (SAMPAIO et al, 2013)

\section{Considerações}

Os alunos demonstraram relevante interesse na Astronomia e na atividade prática da construção dos foguetes de garrafa PET. Segundo relato de alguns alunos, "essa experiência tem um efeito contagiante e desperta o interesse pela Ciência”. Foi uma experiência muito gratificante, que os autores pretendem como trabalho futuro aplicar nos seus estágios.

\section{Referências}

SAMPAIO, T. A. S. M.; RODRIGUES, E. S. Método didático para o ensino de astronomia: utilização do software stellarium em conjunto com aulas expositivas no ensino médio.C\&DRevista Eletrônica da Fainor, Vitória da Conquista, v.8, n.2, p.87-97, jul./dez. 2015.

SAMPAIO, T. A. S. M.; SAMPAIO, P. F. H.; RODRIGUES, E. S. Astronomia no IF Sertão PE Campus Salgueiro: Uma experiência com alunos do ensino médio. XXXI Encontro de Físicos do Norte e Nordeste, Campina Grande, 2013. 